\title{
A NEUTRAL REAL INTEREST RATE IN THE CASE OF A SMALL OPEN ECONOMY: APPLICATION TO UKRAINE
}

\begin{abstract}
ANTON GRUI ${ }^{\text {, VOLODYMYR LEPUSHYNSKYI }}{ }^{\text {, }}$ SERGIY NIKOLAYCHUK ${ }^{*}$
\end{abstract}
\author{
${ }^{a}$ National Bank of Ukraine \\ Email: Anton.Grui@bank.gov.ua

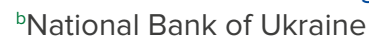 \\ Email: Volodymyr.Lepushynskyi@bank.gov.ua \\ cNational Bank of Ukraine \\ Email: Serhii.Nikolaichuk@bank.gov.ua
}

\begin{abstract}
This paper measures a neutral interest rate in Ukraine by means of applying a Kalman filter to a semistructural model with unobserved components. We rely on a medium-term concept of a neutral interest rate, where it is defined as a real interest rate consistent with output at its potential level and inflation at its target level after the effects of all cyclical shocks have disappeared. Under this concept, and accounting for the small open nature of Ukrainian economy, the neutral interest rate is determined by the global economy's cost of capital and domestic long-term factors that influence risk-premium and changes in the real exchange rate. Conditional on long-term forecasts for output, demographic trends, real exchange rate changes and risk premium, the neutral rate is projected to decrease gradually from its $2.5 \%$ level as of the beginning of 2018 to $2 \%$ in real terms, or to $7 \%$ in nominal terms under a $5 \%$ inflation target. However, in the following years the gap between the National Bank of Ukraine's policy rate and the neutral rate should remain positive - reflecting the tight monetary stance needed to ensure stable disinflation.
\end{abstract}

JEL Codes

C32, E43, E52

Keywords neutral interest rate, Kalman filter, monetary policy stance

\section{INTRODUCTION}

In 1898, Knut Wicksell introduced an idea of a natural rate of interest, at which "the demand for loan capital and the supply of savings exactly agree, and which more or less corresponds to the expected yield on newly created [physical] capital" (p. 193, Wicksell, 1898). Wicksell believed that the natural rate is fully determined by the real sector of economy, and is neutral in respect to commodity prices tending neither to raise nor to lower them. Loan rates have a tendency to adjust to the natural rate, but could diverge from it because of credit expansion by banks. In that case, upward price adjustment continues while there is a gap between loan rates and the natural rate.

Keynes criticized the idea of the Wicksellian natural rate, saying this concept "has anything very useful or significant to contribute". Keynes pointed out that the definition of a natural rate does not imply full employment, and assumes only a stable price level. He replaced the concept of a natural rate with a "neutral" or "optimum" rate of interest, "which prevails in equilibrium where output and employment are such that the elasticity of employment as a whole is zero" (Keynes, 1936). In modern terms, it means that GDP is at its potential level, and the economy is characterized by full employment (thus, employment does not react to additional surges in demand for products, meaning there is zero elasticity).

Current monetary policymaking is based on models that just do not reflect this old debate between the Austrian (which developed Wicksell's ideas) and Keynesian schools of economic thought. Today, for the purposes of monetary policymaking, both the natural and the neutral rates express the same: a medium-term concept of an equilibrium interest rate, which is defined as a short-term, risk free real interest rate consistent with output at its potential level, and inflation at its target level after the effects of all cyclical shocks have disappeared.

In this article we prefer to use term "neutral interest rate" as such an equilibrium rate implies a monetary policy stance providing neither inflationary, nor deflationary pressure. 
Thus, a monetary policy is considered contractionary (expansionary) when the short-term policy interest rate in real terms exceeds (is lower than) the neutral rate. The original Taylor (1993) interest rate policy rule explicitly employs this concept, claiming that the real rate should be above the $2 \%$ "equilibrium" real rate when inflation exceeds its target, and vice versa, all else equal. While in Taylor's original paper lagged inflation serves as a proxy for expected inflation, in practice many central banks exploit inflation forecasts, effectively relying on inflation-forecast targeting (Svensson, 1997). Thus, the neutral interest rate is the level where interest rates converge in a steady state.

In practice, estimating the neutral interest rate is not a trivial task for policy makers. First, it is unobservable variable, and has to be inferred from the data, often with a high degree of uncertainty. Second, while the neutral interest rate should by definition reflect slow-moving, long-term structural factors, these exhibit quite a lot of volatility - especially in emerging market economies undergoing rapid structural changes and recurring financial tensions.

The topic of measuring the neutral interest rate has attracted a great deal of attention in the literature recently. Much of the focus is on advanced economies, where ultra-low interest rates were not able to provide the required stimulus, as the real neutral interest rate fell significantly as well - in the United States it fell from the pre-crisis consensus of $2 \%$ to almost 0\% (Holston et al. (2017), Ball et al. (2016), Carvalho et al. (2016) among others). The main factors behind this decline in real neutral interest rates in advanced economies are considered to be shifting demographics towards an aging and savings-oriented population, slower productivity growth, a general savings glut and persistent weak demand for capital.

In this paper, we focus our analysis on the case of a small open economy and apply it to Ukrainian data. Our empirical approach employs a semi-structural model with unobserved variables by using the Kalman filter algorithm. We exploit data on real GDP, inflation, the exchange rate, and short-term interest rate to extract the long-term trend or equilibrium components of the output, exchange rate and interest rate.

Our approach differs from other research by its strong focus on the features of a small open economy - such as the importance of real exchange rate changes and the risk premium in determining the neutral interest rate. Specifically, we rely on the concept that Ukraine, as a small open economy accepting a price of capital that is determined on the global capital markets and adjusted through risk premium. Besides, this "external" price of capital in foreign currency is decomposed into a neutral interest rate in national currency, and trend real exchange rate changes.

Our analysis yields the following results. First, since 2005 , the neutral interest rate in Ukraine has been very volatile mainly reflecting large swings in the risk premium. Second, most of the time between 2005 and 2015 the National Bank of Ukraine (NBU) allowed a loose monetary stance when the real interest rate was significantly below the neutral level. Such a strongly accommodative monetary policy was the main cause of relatively high and volatile inflation in Ukraine. However, since the beginning of 2016 the NBU has maintained its key policy rate in real terms well above the neutral interest rate, thus ensuring disinflation in accordance with the announced inflation targeting framework. Third, projections of the neutral interest rate, based on forecasts for productivity, demographic trends, real exchange rate changes, and the risk premium, suggest that the neutral rate is likely to gradually decrease from $2.5 \%$ at the beginning of 2018 to $2 \%$ in real terms, or to $7 \%$ in nominal terms under the $5 \%$ medium-term inflation target. However, the current gap between the NBU's policy rate and the neutral rate in the following years should remain positive, reflecting the tight monetary stance needed to ensure stable disinflation.

The rest of the paper proceeds as follows. The second section provides a brief review of the literature, while the third section presents the analytical framework employed for the empirical assessment of the neutral rate in Ukraine. The results and their interpretation are described in the fourth section. The final section presents our conclusions.

\section{LITERATURE REVIEW}

Despite the central role of neutral interest rate in the Taylor rule, the literature on the topic of measuring real neutral interest rates has flourished recently. The seminal paper of Laubach and Williams (2003) introduced Kalman filter estimates of the US neutral rate, leading to widespread applications of semi-structural models augmented by statistical filters and state space representations among central banks (e.g. Baksa et al. (2013) and Kreptsev et al. (2016) for emerging markets). Other popular methods include:

(1) applying simple statistical filters such as the HodrickPrescott, Ravn-Uhlig, and Christiano-Fitzgerald time-varying filters (e.g. Perelli and Roache (2014) applied these filters for ex-post real interest rates in Ukraine and other countries, and found that in Ukraine the real neutral rate fluctuated from $3.2 \%$ in $2002-2004$ and $-4.4 \%$ in $2005-2008$ to $3.1 \%$ in 2010-2013, exhibiting one of the highest variations in the sample of countries);

(2) using Dynamic Stochastic General Equilibrium (DSGE) models (often New-Keynesian models), which impose relationships between the variables based on economic theory, with a view to building an "ideal" economy of full employment or of flexible prices and wages (e.g. Barsky et al. (2014), Del Negro et al. (2015), and Curdia et al. (2015));

(3) assessing an implicit natural rate from the co-movement of the yields of financial instruments, or by estimating the slope of the yield curve (e.g. Giammarioli and Valla, 2004, Basdevant et al., 2004).

Simple statistical filters are poorly suited to the Ukrainian case, where the real interest rate has been characterized by pronounced volatility in the past, due to both highly volatile inflation and nominal interest under a hard exchange rate peg. Instead, semi-structural models, imposing mild theoretical restrictions, account for additional information from other macroeconomic indicators, such as inflation and output, during the estimation. Another important advantage of a more structural approach is that by imposing some fundamental constraints, it is easier to disentangle to what extent volatility in certain periods reflects movements in the neutral rate, or movements in the policy stance. This cannot be done with simple filters.

On the contrary, DSGE models impose too strong theoretical restrictions thatare more prone to misspecification, especially in the presence of near-nonstationarity in 
observed real rates (Pescatori and Turunen, 2015). Besides, neutral interest rates derived through DSGE models can vary
Figure 1 presents all of the above-mentioned rates and concepts schematically.

\section{Figure 1. Decomposition of short-term nominal rates}

\begin{tabular}{|c|c|c|c|}
\hline \multicolumn{4}{|c|}{ Observed nominal interest rate } \\
\hline \multicolumn{3}{|c|}{ Ex ante real interest rate } & \multirow[b]{3}{*}{$\begin{array}{l}+ \text { Expected } \\
\text { inflation }\end{array}$} \\
\hline Neutral real & interest rate & & \\
\hline $\begin{array}{l}\text { Long run equilibrium (or } \\
\text { steady state) real interest rate }\end{array}$ & $\begin{array}{c}\text { + Medium-term economic } \\
\text { factors (demographics, } \\
\text { productivity, capital flows, risk } \\
\text { premium etc.) }\end{array}$ & $\begin{array}{l}\text { + Monetary } \\
\text { policy reaction } \\
\text { (cyclical factors) }\end{array}$ & \\
\hline
\end{tabular}

substantially, depending on the specific assumptions in the model. Equations of semi-structural models are inspired by the structural equations of New-Keynesian models, but take a more flexible form. Compared with the DSGE approach, the use of semi-structural models imposes fewer economic constraints on the data and, as a result, is more robust in the case of possible errors in model specification.

Relying on financial market information is a promising topic, but one for future research in the Ukrainian case, due to the market being underdeveloped, and presence of only a short sample of active monetary policy (the transition to inflation targeting occurred only in 2015).

The prevailing theoretical concept used in semi-structural and DSGE models defines a neutral interest rate as one that equilibrates savings and investment, and does not create either inflationary or deflationary pressures. This means that a neutral interest rate is the rate of interest that should prevail in the medium term after the effects of business cycle shocks disappear, and output stabilizes at its potential (or full employment) level. Thus, the deviation of the observed policy rate from the neutral one determines the stance of monetary policy.

At a global level (or in a closed economy) the main role in determining the neutral interest rate is played by the Euler equation, which makes a consumer indifferent between extra consumption and savings, and links the neutral interest rate with potential output growth. ${ }^{1}$ It provides the framework for analyzing the determinants of the neutral interest rate through their influence on saving and investment. Among these determinants are long-term fundamentals such as households' propensity to save, demographic trends, and technological advances - as well as medium-term factors like productivity shocks, imbalances in private or public sector savings, and financial market or economic policy disturbances that in various ways affect saving or investment decisions.

Considering a sufficiently long period to enable all markets to clear and all economic variables to settle at constant growth rates, and in the absence of new shocks, we come up with the long-term equilibrium or steady state of the economy, and so the equilibrium interest rates under long-term concept.
However, even accepting the concept of a neutral interest rate consistent with a zero output gap in the medium term, relying exclusively on domestic factors that determine savings and investments is not a good approach for a small open economy, where the gap between savings and investment can be covered by capital inflows. Mendes (2014) indicates that domestic demand for investment in an open economy is conditioned by not only the domestic availability of savings, but the net supply of foreign savings as well. Moreover, if a country is a pure price-taker, then domestic forces do not matter at all, and the neutral interest rate is determined by external ones exclusively. Perrelli and Roache (2014) also show that in emerging market economies, the real rates depend heavily on global factors that determine both trends and cyclical movements. The IMF (2014) proves that common global factors play an increasingly important role for interest rates as international financial integration expands.

However, according to Perrelli and Roache (2014), the neutral interest rate can be partially influenced by internal factors in the case of less-than-perfect financial integration. Moreover, a country may be subject to a sovereign risk premium, which also depends on domestic factors. Mendes (2014) proposes domestic net foreign assets as a source for such a premium. The size of the premium decreases if foreign assets are accumulated domestically. Among other internal factors are credit spreads and potential output growth. The former reduces investments and increases savings, thus lowering the neutral interest rate. The latter reflects productivity growth and presumably shapes demand for investment. However, the author remains uncertain about the relative importance of domestic and foreign factors for the Canadian economy.

Kreptsev et al. (2016) state that the neutral interest rate must remove arbitrage between investments in physical and financial assets as well as domestic and foreign ones (through uncovered interest parity). The literature often considers these conditions separately, but they may be coherently combined in a general equilibrium model. The authors examine different approaches for calculating the neutral interest rate, and obtain a wide variety of assessments for the Russian economy.

Among the recent work on estimating neutral interest rates in emerging economies it is worth mentioning Stefański (2017), who adds some innovations to the method developed by Laubach and Williams (2003), applying it to economies 
in Central and Eastern Europe (CEE). He concludes that neutral rates declined from pre-crisis levels (before 2008) in CEE countries as a result of spillovers from developed economies. The main channel of such spillover is the decline in potential output growth rates because of global factors. Population aging in the euro area also contributed to the fall in neutral rates, but only marginally.

\section{ANALYTICAL FRAMEWORK}

In a closed economy or at the global level, all investments must be financed by savings, thus these two are equal. Equilibrium is found at the intersection of the propensity to save and the propensity to invest (Figure 2, left). The former increases with returns, while the latter decreases with costs.

In a small open economy, in contrast, savings do not need to be equal to investments. In fact, Ukraine invests more than it saves. The difference is covered by foreign capital flows, for which Ukraine is a price-taker. However, the available amounts of capital inflows are virtually unlimited, which means that the capital supply curve is flat (Figure 2 , right).
Thus, for the purposes of our research, we use the argument that global factors are the prevailing determinants of the cost of capital for Ukraine. Meanwhile, the risk premium also depends on domestic, country-specific factors, such as fiscal and external sustainability, political turbulence, banking sector performance, demographic changes, and so on.

We use the uncovered interest rate parity (UIP) as the central point to calculate the neutral real interest rate in the medium-term perspective:

$$
r=r^{*}-\Delta z+r p
$$

where

$r^{*}$ is the world real interest rate (or global cost of capital);

$\Delta z$ is the expected change in the real exchange rate, where an increase means the appreciation of the local currency. Real exchange rate appreciation means that domestic assets become more valuable. Thus, an investor receives income not only in the form of interest payments in local currency, but additionally from the appreciation of the

\section{Figure 2. Difference in determining real neutral interest rate in closed economy and in a small open economy}

Large closed (global) economy

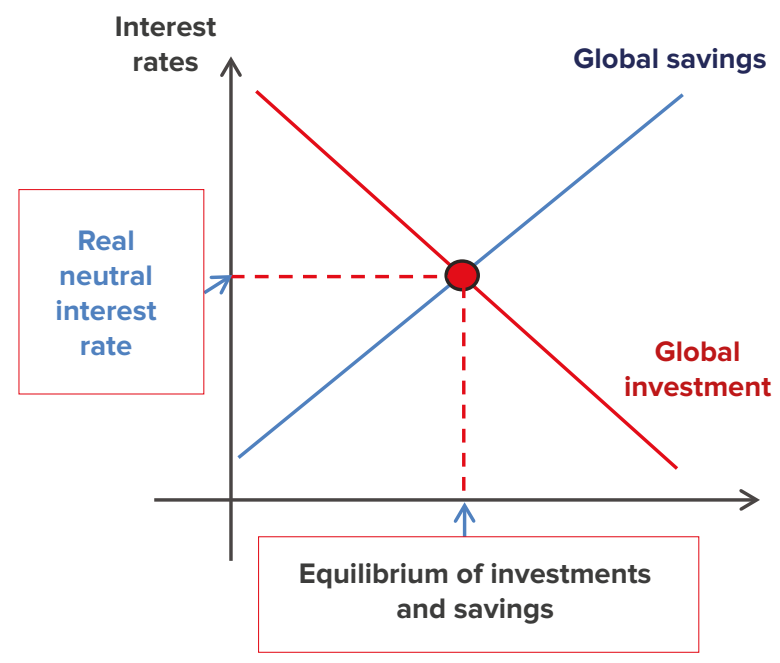

Ukraine is a typical small open economy. Its share in global GDP is minor (0.1\% in 2016 according to World Bank data) and the share of external trade turnover to GDP exceeds $100 \%$. Meanwhile, the Ukrainian financial market is shallow and tiny.

Thus, it is a reasonable assumption that domestic economic developments in Ukraine do not influence global interest rates. This is also one of the assumptions made by Mundell (1963) during his study of the Canadian case. Of course, we cannot use Mundell's other assumption of the indefinite persistence of the existing exchange rates. Instead, we have to take into consideration the movements of exchange rates needed to satisfy interest rate parity.

We also need to adjust another of Mundell's assumptions on perfect capital mobility - meaning that international capital flows fully equalize world and domestic interest rates. However, in the case of Ukraine, the county-specific risk premium has to be taken into account.
Small open economy

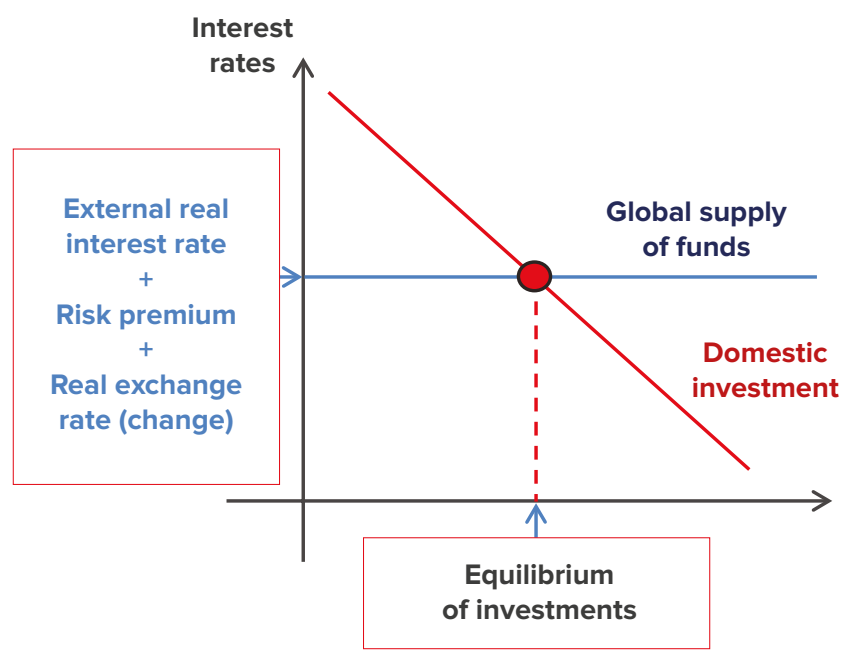

local asset's value. Consequently, higher income from a real appreciation (due to nominal exchange rate appreciation and/or higher growth in domestic prices) means that an investor would agree to a lower interest rate in local currency.

In case of an emerging market economy, this reflects the Balassa-Samuelson effect or the process of "catching up" with advanced economies. The faster productivity growth in a developing economy leads to an appreciation of the real exchange rate. Other factors also have a hand in determining real exchange rate dynamics. In fact, in estimating longterm real exchange rate, following the logic of the External Balance Assessment methodology developed by Phillips et al. (2013), we take into consideration a set of domestic factors. However, we also compare these domestic factors with the relevant factors in the global economy. Such an approach is consistent with the concept of a small open economy - which is the central point of our research. 
$r p$ is country-specific risk premium. Investors require compensation for entering the domestic market. It reflects all other factors apart from interest and exchange rates. For instance, Archibald and Hunter (2001) indicate the following factors that increase the risk-premium:

- large and persistent debt positions; ency;

poor-quality economic policy and inadequate transpar-

- concerns over unexpected currency moves;

- small or illiquid markets making it more difficult or costly to pull out of an investment.

We consider the method of determining the neutral interest rate based on UIP as the most relevant in the case of Ukraine, especially for policy-making purposes. The logic behind methods based on exclusively domestic determinants of a neutral policy rate could misguide monetary policy in the case of a small open economy. For example, in the case of the Euler equation, higher potential GDP growth leads to a higher neutral rate. This logic works well for large closed economies in the long run, but in the medium term in a small open developing economy higher potential GDP growth leads to faster convergence of the economy with the developed world, and correspondingly to stronger real appreciation and a lower risk premium. That drives the neutral interest rate down.

Over an historical period, the estimation of the neutral interest rate is made with the help of the Quarterly Projection Model (QPM) of the NBU. The model is based on NewKeynesian theory (Nikolaychuk and Sholomytskyi, 2015). In this way, the neutral interest rates obtained from UIP are consistent with other trend variables, such as real exchange rate trend and potential output.

One can argue that Ukraine has widely used capital controls and is currently cut off from the international financial market. In such circumstances, domestic conditions may have some degree of autonomy from international markets. That could be relevant in the short term. However, we are considering the neutral interest rate in the medium term. In this case, capital controls lose relevance.

There is vast amount of literature supporting such an assumption. Many researchers find no or little evidence that capital controls have an effect on monetary policy autonomy, e.g. the formation of domestic interest rates. De Gregorio et al. (2000) conclude that capital controls have no significant effect on interest rate differentials and the real exchange rate. Miniane and Rogers (2007) discover no evidence that capital controls effectively insulate countries from U.S. monetary shocks. Forbes and Warnock (2012) find little association between capital controls and the probability of having surges or halts in foreign capital flows. Gunnarsdóttir and Rehnholm (2011), in their case study of Iceland, argue that capital controls do not enhance monetary policy autonomy, but have positive effects on smoothing exchange rate volatility. Pasricha et al. (2015) find limited evidence of the effectiveness of capital control measures on monetary autonomy or exchange rates.
Ukraine has always had some forms of capital controls. However, these did not insulate the economy from monetary conditions in the leading advanced economies, due to large international capital surges. Inflows of cheap capital in 2005-2008 heavily contributed to the overheating of Ukrainian economy. In the autumn of 2008, after the bankruptcy of Lehman Brothers, capital flows reversed, plunging the economy into a deep recession. The severe capital restrictions introduced at that time did little to fix the situation (Saborowski et al., 2014).

\subsection{Description of the model}

The NBU deploys an open-economy forward-looking New-Keynesian Quarterly Projection Model with a view to explaining the core macroeconomics dynamics in Ukraine. The QPM is a "gaps" model, as it captures the general equilibrium (trends) of the system and explains the dynamics of variables' deviations from trends (gaps). In particular, it tracks how gaps evolve and dissipate with time. The trends and gaps are unobservable (state) variables estimated with the Kalman filter.

The QPM is a small semi-structural model with rational expectations. As long as its equations are derived from microeconomic principles and comprise of forward-looking variables, the model is not subject to the Lucas critique (Lucas, 1976).

The origins of the model came from a QPM of the Bank of Canada (Coletti et al., 1996) and the Czech National Bank (Coats et al., 2003). The basic properties of the Ukrainian version are described in Grui and Lepushynskyi (2016). Currently, similar models are used by the central banks of Armenia, Romania, Serbia, the Slovak Republic and many others.

The QPM is constructed to describe the monetary policy transmission mechanism. On the one hand, it shows a macroeconomic environment that actively responds to monetary policy shocks in the short term. On the other hand, a neutral monetary policy is consistent with medium-term inflation target and potential GDP.

The model comprises about 50 equations, which are not simple definitions or identities. The parameters are calibrated rather than estimated, with a view to reflecting theoretical principles, and provide worthy modeling properties. Below we discuss the main equations that are essential for the study.

\section{Aggregate demand curve}

Output gap (ŷ) behavior is modeled in the following equation:

$$
\begin{gathered}
\hat{y}_{\mathrm{t}}=\alpha_{1} \hat{\mathrm{y}}_{\mathrm{t}-1}+\beta_{1} \hat{\mathrm{y}}_{\mathrm{t}+1}-\gamma_{1} \hat{\mathrm{z}}_{\mathrm{t}-1}-\delta_{1} \widehat{\mathrm{Ir}}_{\mathrm{t}-1}+ \\
+\theta_{1} \widehat{\mathrm{w}}_{\mathrm{t}}+\vartheta_{1} \hat{\mathrm{y}}_{\mathrm{t}}^{*}+\mu_{1} \widehat{\operatorname{tot}}_{\mathrm{t}}+\rho_{1} \mathrm{f}_{\mathrm{t}}+\varepsilon_{1, \mathrm{t}}
\end{gathered}
$$

Equation (1) is the first to represent the "gaps" nature of the model. The output gap is estimated in terms of the percentage deviation of GDP from its potential level, which is represented by the difference in logarithms. It is designed to express the pressures of demand in an economy. 
The current output gap, calculated on a quarterly basis, depends on both its own lagged values and model-consistent expectations. These smooth the estimates, as they account for overlapping contracts and consumer sentiments. Next, the gaps in the GDPs of main trading partners $\left(\hat{y}^{*}\right)$, terms of trade $(\widehat{t o t})$ and real ER $(\hat{z})$ allow external demand dynamics to be taken into account - these dynamics correspond to a large share of aggregate demand in a small open economy. The real wages gap $(\hat{w})$ captures spillovers from the labor market. Finally, other important factors in the aggregate demand dynamics are the real long-term interest rate (combining real short-term policy rate and credit premium) gap $(\widehat{l r})$ and the fiscal impulse (f). These represent the effects of monetary and fiscal policies respectively.

\section{Aggregate supply curve}

Overall inflation in the model is broken down into Core, Raw foods, Fuel and Administratively regulated components. Equation (2) depicts the general idea behind inflation, as it models Core inflation ( $\pi^{\text {core }}$ ) in the form of a forward-looking Phillips curve:

$$
\begin{gathered}
\pi_{\mathrm{t}}^{\text {core }}=\alpha_{2} \pi_{\mathrm{t}-1}^{\text {core }}+\beta_{2} \pi_{\mathrm{t}+1}+ \\
+\left(1-\alpha_{2}-\beta_{2}\right)\left(\pi_{\mathrm{t}-1}^{*}-\Delta \mathrm{s}_{\mathrm{t}-1}+\Delta \overline{\mathrm{z}}_{\mathrm{t}-1}\right)+ \\
+\gamma_{2} \hat{\mathrm{y}}_{\mathrm{t}}-\delta_{2} \hat{\mathrm{z}}_{\mathrm{t}-1}+\theta_{2} \widehat{\mathrm{w}}_{\mathrm{t}}+\vartheta_{2}\left(\pi_{\mathrm{t}}^{\text {food }}-\pi_{\mathrm{t}}^{\mathrm{T}}\right)+\varepsilon_{2, \mathrm{t}} .
\end{gathered}
$$

Firstly, Core inflation (annualized quarterly changes) is to a great extent determined by its own past values and by projected overall inflation $(\pi)$. It depicts the weights of adaptive and rational inflation expectations, and links Core inflation to other inflation components. Secondly, the equation incorporates imported inflation, consisting of changes in the prices of the country's main trading partners $\left(\pi^{*}\right)$, changes in nominal effective ER $(\Delta \mathrm{s})$ as well as changes in the trend of real ER $(\Delta \overline{\mathrm{z}})$. The latter positively contributes to inflation if it appreciates, which is a way to model the Balassa-Samuelson effect. It accounts for accelerated prices of non-tradable goods in an emerging economy. Further, gaps in GDP, real ER and real wages allow for real marginal costs to be accounted for. The last term represents spillovers from Raw foods inflation $\left(\pi^{\text {food }}\right)$ relative to inflation target $\left(\pi^{\top}\right)$. Some of the factors influence Core inflation with a one-quarter delay.

\section{Monetary policy rule}

The short-term policy rate $\left(i_{t}\right)$ is taken as a monetary policy instrument, and equation (3) represents the monetary policy reaction function:

$$
\begin{gathered}
\mathrm{i}_{\mathrm{t}}=\alpha_{3} \mathrm{i}_{\mathrm{t}-1}+ \\
+\left(1-\alpha_{3}\right)\left(\overline{\mathrm{r}}_{\mathrm{t}}+\pi_{\mathrm{t}+1}^{\mathrm{T}}+\beta_{3}\left(\pi 4_{\mathrm{t}+3}^{\exp }-\pi_{\mathrm{t}+3}^{\mathrm{T}}\right)+\gamma_{3} \hat{\mathrm{y}}_{\mathrm{t}}\right)+ \\
+\varepsilon_{3, \mathrm{t}} .
\end{gathered}
$$

It follows a modified Taylor rule. Markets are assumed to incorporate changes in the policy rate in long-term credit rates.

The nominal policy rate is a function of its own lagged value. This introduces a smoothing effect, as the NBU, in line with other central banks, typically demonstrates persistence in its policy decisions. The policy rate reacts to changes in the nominal neutral rate, which is the sum of the real neutral rate $(\overline{\mathrm{r}})$ and next quarter's inflation target. Furthermore, the policy rate responds to the deviation of projected annual inflation $\left(\pi 4^{\exp }\right)$ from the target and the present output gap. Monetary policy impacts inflation only after a certain delay. Therefore, it needs to react preemptively to deviations from targets, and contemporaneously to the output gap, as this affects future inflation.

Long-term uncovered interest rate parity condition in real terms

Equation (4) shows how the real neutral interest rate $(\bar{r})$ is calculated:

$$
\bar{r}_{t}=\bar{r}_{t}^{*}-\Delta \bar{z}_{t+1}+\overline{r p}_{t} .
$$

It models the long-term financial relationship with the rest of the world.

The arbitrage condition states that, at equilibrium, the real return on capital available domestically and abroad should be equal. Thus, the domestic neutral real interest rate has to cover foreign real returns on capital $\left(\bar{r}^{*}\right)$ and account for expected changes in the real ER. If investors expect the domestic currency to appreciate in real terms, they will accept lower yields. However, investors might require a risk premium for investing in a more vulnerable country.

\section{Trend in real exchange rate}

Equation (5) models trend in the real ER in the economy as following relative growth in potential output (reflecting the Balassa-Samuelson framework):

$$
\begin{gathered}
\Delta \bar{z}_{t}=a_{5} \Delta \bar{z}_{t-1}+\left(1-a_{5}\right) b_{5}\left(\Delta \bar{y}_{t}-\Delta \bar{y}_{t}^{*}\right)+ \\
+\gamma_{5} \Delta \overline{t o t}_{t}+\varepsilon_{5, t} .
\end{gathered}
$$

Changes in the trend in real ER are smoothed, as they depend on lagged values. The real ER is modeled to appreciate in a steady state, which is due to projected differences in productivity growth compared with trade partners. This is attributable to the Balassa-Samuelson effect, which originates from the assumption about the real convergence of the Ukrainian economy. The envisaged deviations from the Balassa-Samuelson framework come in combination with trend shifts in terms of trade. The large share of tradable goods in the economy forces real ER to appreciate with favorable terms of trade, and vice versa.

\section{RESULTS}

\subsection{Empirical implementation}

We apply the Kalman filter in order to consistently estimate unobservable variables such as the neutral real interest rate and its determinants, namely trends in the real exchange rate and risk premium. These are supplemented with the real neutral rate for the US, estimated using the Laubach and Williams (2003) methodology. This method allows the combining of actual data with assumptions about developments in unobserved variables (as presented in the previous section on model structure).

The data and specifics of model variables are described in Table 1. 
Table 1. Model variables description

\begin{tabular}{|c|c|c|}
\hline Variable & Definition & Source \\
\hline Nominal short-term interest rate & Nominal average interbank overnight rate & NBU \\
\hline Real short-term interest rate & $\begin{array}{l}\text { Nominal short-term interest rate minus } \\
\text { model-consistent inflation expectations }\end{array}$ & NBU; own estimates \\
\hline Nominal long-term interest rate & $\begin{array}{l}\text { Average interest rate on loans to non-finan- } \\
\text { cial corporations in UAH }\end{array}$ & NBU \\
\hline $\begin{array}{l}\text { Nominal short-term interest rate } \\
\text { in US dollars }\end{array}$ & 3 months LIBOR in US dollars & Thomson Reuters \\
\hline $\begin{array}{l}\text { Real neutral interest rate } \\
\text { in US dollars }\end{array}$ & $\begin{array}{l}\text { Natural interest rate in the US estimated } \\
\text { using Laubach and Williams (2003) method- } \\
\text { ology }\end{array}$ & $\begin{array}{l}\text { Federal Reserve Bank } \\
\text { San Francisco }\end{array}$ \\
\hline $\begin{array}{l}\text { Nominal exchange rate } \\
\text { to the US dollars }\end{array}$ & $\begin{array}{l}\text { Official nominal exchange rate, } \\
\text { UAH per US dollars }\end{array}$ & NBU \\
\hline
\end{tabular}

Real exchange rate to the US dollars

Nominal effective exchange rate

Real effective exchange rate

Risk premium

GDP

GDP of main trade partners

Nominal wages

Real wages

Terms of trade
Nominal UAH/USD exchange rate adjusted for CPI inflation in Ukraine and in the United States

Weighted average of nominal exchange rates for main trading currencies (euro, US dollar, Russian ruble)

Nominal effective exchange rate adjusted by inflation rates in Ukraine and in the issuers of the main trading currencies (the Euro Area, the United States, the Russian Federation)

Difference between yields on sovereign state euro-bonds denominated in US dollars and 10Y US Treasuries

Seasonally adjusted quarterly gross domestic product in real terms

Weighted average of real gross domestic products in main trade partners or proxies (Euro Area, Turkey, Russian Federation)

Average before tax monthly wages of employees

Nominal wages deflated by consumer price index

Ratio of weighted average of prices for main exported (grains, metals) and main imported (oil, gas) commodities
NBU; State Statistics Service;

Thomson Reuters; own estimates

NBU, Thomson Reuters, own estimates

NBU, Thomson Reuters, own estimates

Cbonds; own estimates

State Statistics Service, own estimates

National Statistics Agencies, own estimates

State Statistics Service

State Statistics Service, own estimates

World bank, own estimates
Thereafter, we report the estimation results, focusing first on the determinants of the neutral real interest rate, and then on the rate itself.

Trend in the real exchange rate

Ukraine is an emerging market economy. Thus, considering the Balassa-Samuelson effect, it is supposed to enjoy faster productivity growth than in advanced economies, and stable real ER appreciation in a steady state. This is a reasonable assumption for the long-term perspective; but it is not historically the case (Figure 3). Over the last ten years, Ukraine has experienced two major devaluations - in 2008 and then in 2014-2015, determining the real ER depreciation trend. 
Figure 3. Real exchange rate trend growth and its determining factors, $\%$

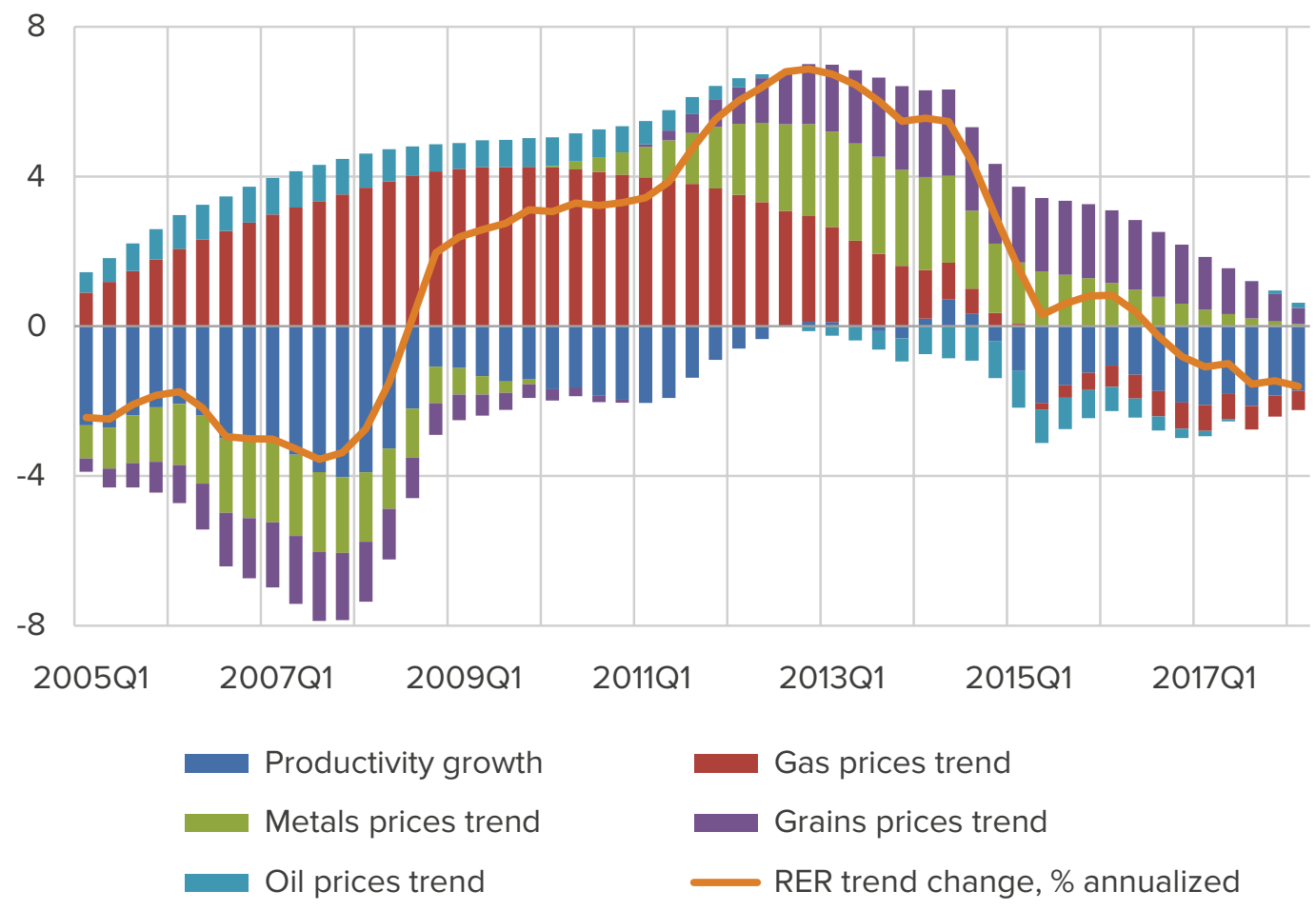

Such depreciation trend can be explained by two main factors - worsening terms of trade and low productivity growth. First, about 70\% of Ukraine's trade is in raw commodities, with grains and base metals being the main exported goods, and oil products and natural gas - the main imported ones. The global commodities markets have been unfavorable for Ukraine over the last ten years, reflecting the global commodities super cycle. The real ER lost almost 30\% over the same period.

Until 2014, the continuous increase in natural gas import prices was the main reason for the deterioration in the terms of trade. However, before 2008 its negative effect was compensated for by a surge in prices for exported commodities. The terms of trade trend was stable, and the real ER was appreciating. After the global financial crisis, the prices for grains and base metals were able to recover quickly, but their trends were set to decline. There was nothing to compensate for the upward trending oil and natural gas prices. This was enough to create adverse trend in terms of trade and RER. In 2014, the prices of imported commodities dropped, which allowed the RER to stabilize.

A large chunk of the remaining RER depreciation trend was due to lower than expected productivity growth. Potential GDP never recovered after the financial crisis, and was stalled until 2014. There was a setback in reforms, and Ukraine dropped in the international rankings. The business climate worsened, in contrast to the situation seen up until 2009, when productivity was fast improving in line with the real convergence process.

The situation with productivity has been improving since 2015, while the contribution of the terms of trade trend has been fading. As a result, at the beginning of 2018 the trend in the real appreciation of the domestic currency was close to $1.5 \%$.

\section{Sovereign risk premium}

We use the difference between the yield on Ukraine's sovereign Eurobonds in USD and US treasury bills to express the risk premium. Such a variable is an appropriate proxy for the risk premium, as it represents solely the risk of default by the state, and excludes other risks, such as:

- exchange rate risk - as both Ukraine's sovereign Eurobonds and US treasury bills are nominated in USD;

- legal risks - as Ukraine's sovereign Eurobonds are issued under international law;

- transaction costs - as both securities are traded internationally and there is no need for investors to enter local markets and be subject to domestic FX regulations.

In addition, the benefit of using such a proxy is that data is available with the appropriate frequency.

The premium has been above 3\% ever since 2008 (Figure 4). Moreover, it surged abnormally twice during the crises episodes. The risk premium first hiked in 2009, when the financial crisis increased global risk averseness. Capital flows relocated from Ukraine as the risks grew. Subsequently, the premium lowered in line with initial success of the Stand-by program of the IMF, the exchange rate adjustment, and mitigated risks. From 2011 to 2013, the risk premium continuously increased, as investors' sentiments were undermined. This was due to Ukraine's inconsistent macroeconomic policy and worsening business climate. From 2014 to 2015, the sovereign risk premium spiked again, reflecting the escalation of the military conflict in eastern Ukraine. Since then it has gradually decreased until the present time. 
Figure 4. Sovereign risk premium and its trend, \%

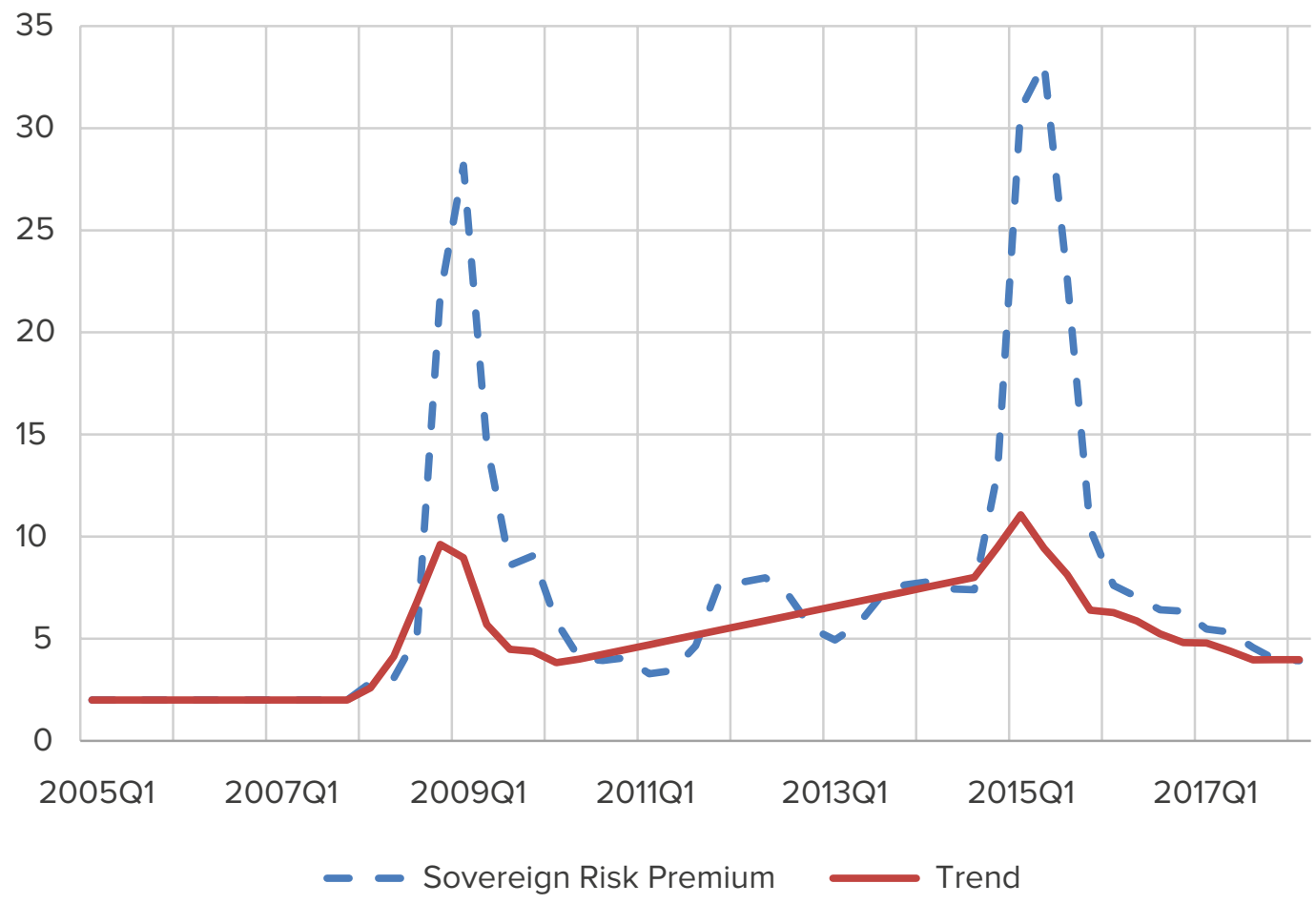

For the sake of calculating the neutral interest rate, we employ the risk premium trend. It reflects the overall dynamics of the indicator, but mitigates, in particular, for excessive volatility and abnormal surges. At the beginning of 2018 , it was close to $4 \%$.

\section{Real neutral interest rate in the US}

To determine the global cost of capital, we use smoothed estimates of the natural rate of interest in U.S. obtained using Laubach-Williams (2003) methodology, which are published by the Federal Reserve Bank of San Francisco (Figure 5). These estimates have declined significantly over the last 13 years, which is due to shifts in world supply and demand for funds. In 2017 and at the beginning of 2018, the natural rate of interest in USD was close to zero. Holston et al. (2017) explain this as being due to the ageing population, the global savings glut, and slowing potential growth. The authors also show that these factors are common for several other advanced economies.

Figure 5. Neutral real interest rate in the US, \%

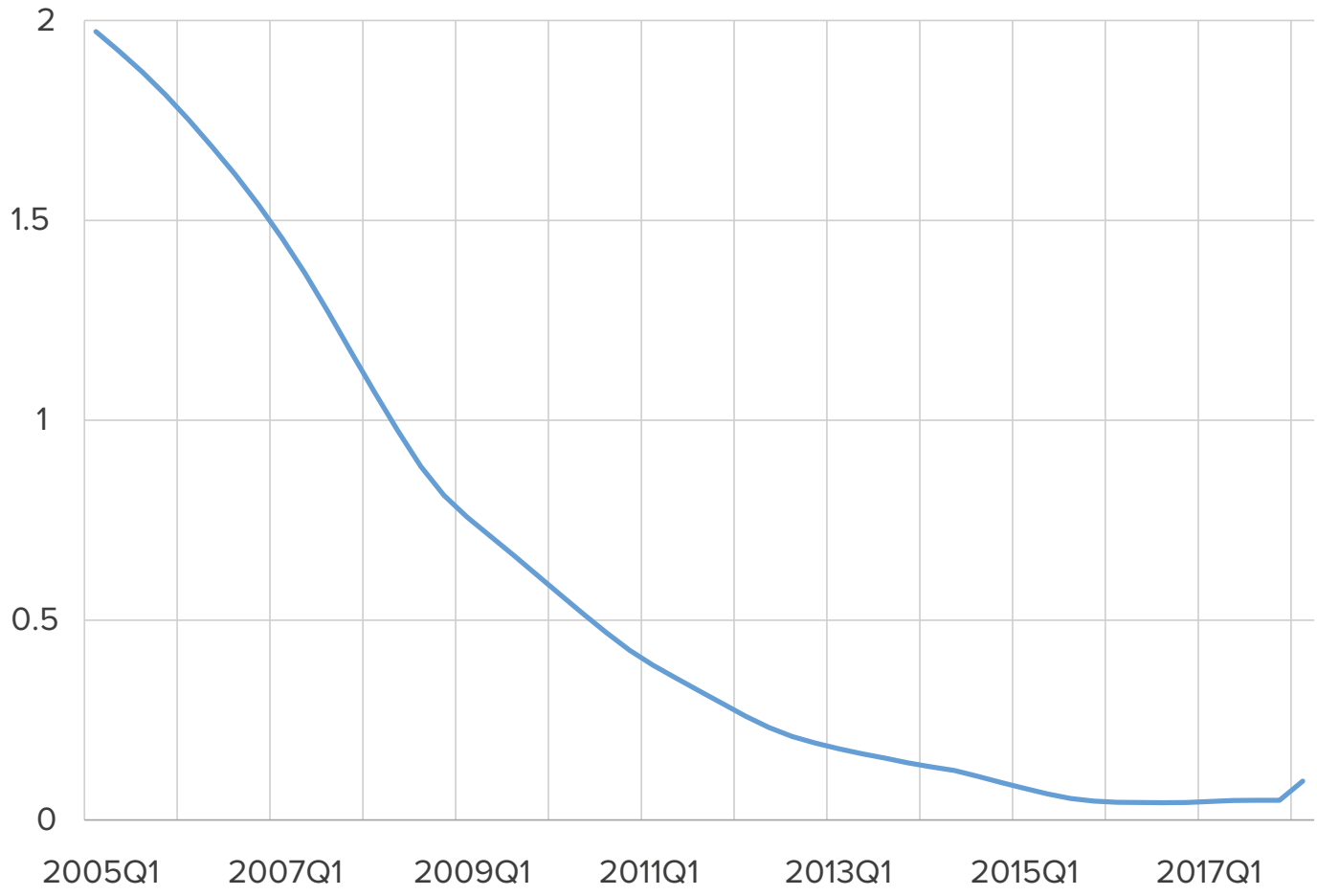




\section{Real neutral interest rate in Ukraine}

The combination of the above-mentioned factors shapes the dynamics of the neutral real interest rate in Ukraine (Figure 6). From 2005 to 2007, the neutral rate fluctuated between $0 \%$ and $2 \%$ on the background of a low risk premium and appreciating real ER. In general, the rate in Ukraine was decreasing in line with its US counterpart, and even used to be below it.

\section{Assessing monetary stance}

We now focus on the behavior of the real interest rate, defined as the nominal short-term interest rate adjusted for expected inflation. A key policy rate was de-facto absent in Ukraine until 2014, since the former monetary policy framework relied on an exchange rate peg against the US dollar. To reflect the monetary policy stance at that time, we used the overnight interbank interest rate. Under the current

Figure 6. Real neutral interest rate decomposition, \%

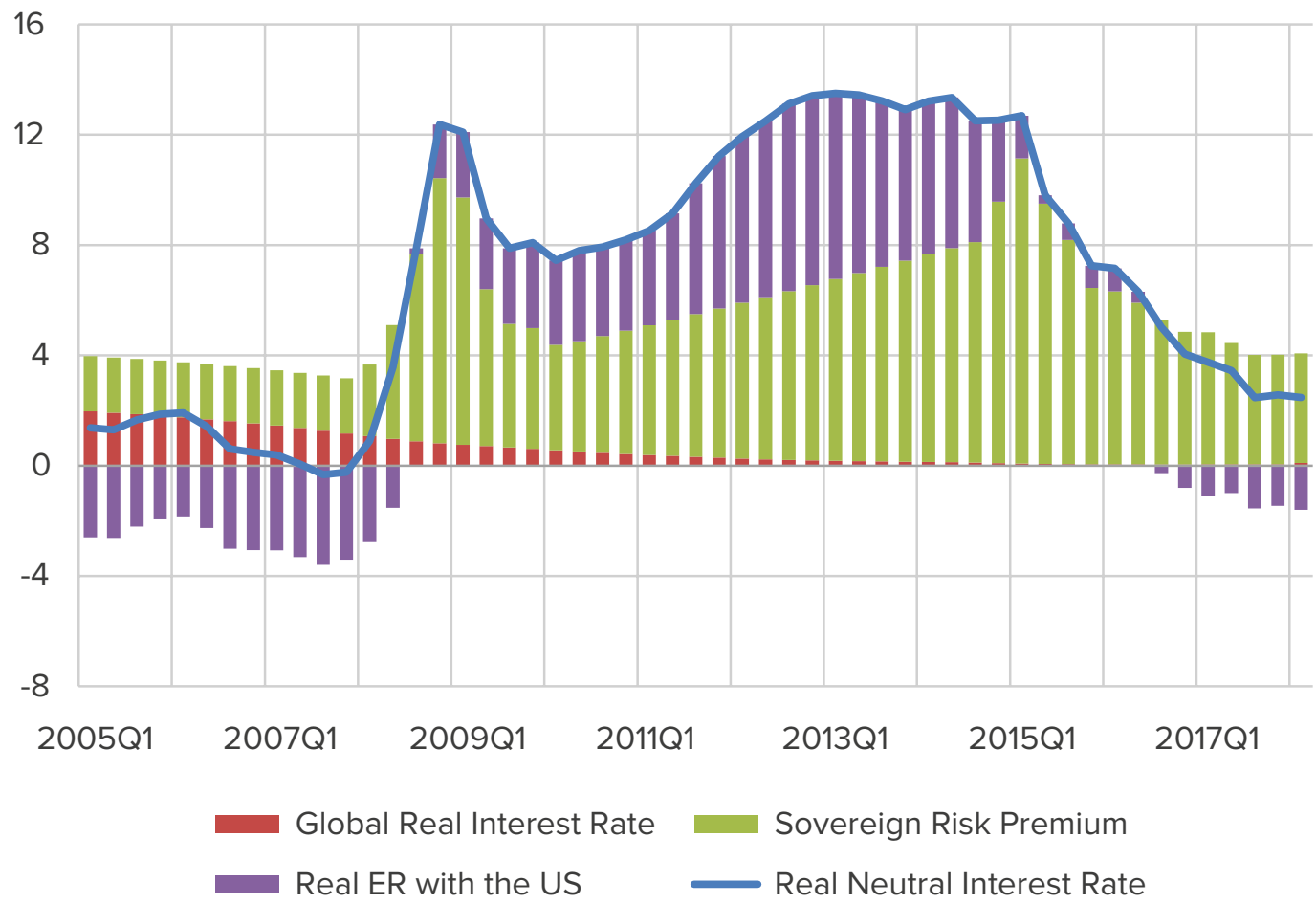

However, the hike in the sovereign risk premium and simultaneous break in the real ER trend caused a surge in the real neutral rate to $12 \%$ in $2008-2009$. The mitigated risk premium in 2010 brought some relief, with the rate rolling back to about 7\%. However, until 2015 the neutral rate in Ukraine was increasing, in contrast with the decreasing rate in the US. It reached $13 \%$ in 2014 , as both the growing risk premium and the real ER depreciation trend had unfavorable effects. In 2015, the neutral rate was above $15 \%$, mostly due to a surge in the risk premium.

As of the beginning of 2018 , the rate is close to $2.5 \%$ and continues to decrease with the return to a real ER appreciation trend and a lowering risk premium, as well as a low rate in the United States. inflation targeting framework, this interest rate plays the role of an operational policy target. Such an approach allows us to conduct a continuous analysis in a situation in which there is a switch in monetary policy regimes.

The concept of the neutral interest rate provides a useful tool for an ex-post monetary policy analysis. Figure 7 plots the estimated real neutral rate. The persistent negative gap between the overnight interbank rate and the neutral rate evidences in favor of there being a highly accommodative policy stance for most of the historic horizon. 
Figure 7. Monetary policy stance, $\%$

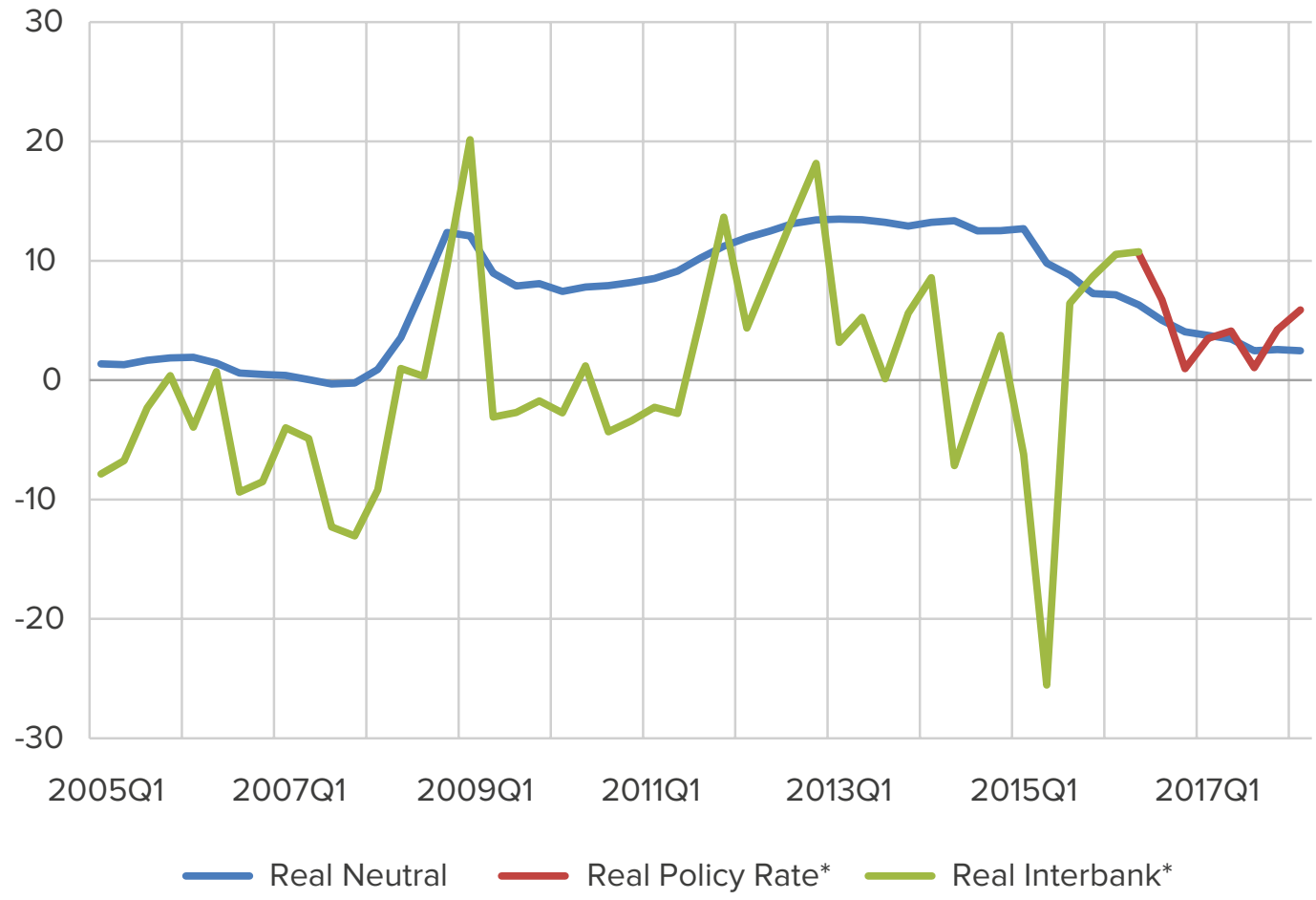

Since 2005, there were only eleven quarters during which the real interbank rate was on average above its neutral level (Figure 8). Seven of them were in the period since 2015, which testifies to there being a strict monetary policy with a view to achieving a disinflationary trend. The other five were due to devaluation pressures and reflected efforts to protect the fixed exchange rate - they were mainly in late 2011 and 2013. The tight monetary stance contributed to the recession and close to zero inflation in 2012 and 2013. However, the exchange rate peg to the US dollar at an overvalued level contributed to low inflation even more, and finally resulted in currency crisis in 2014.

Figure 8. Real Interest Rate Gap and Consumer Inflation, \%

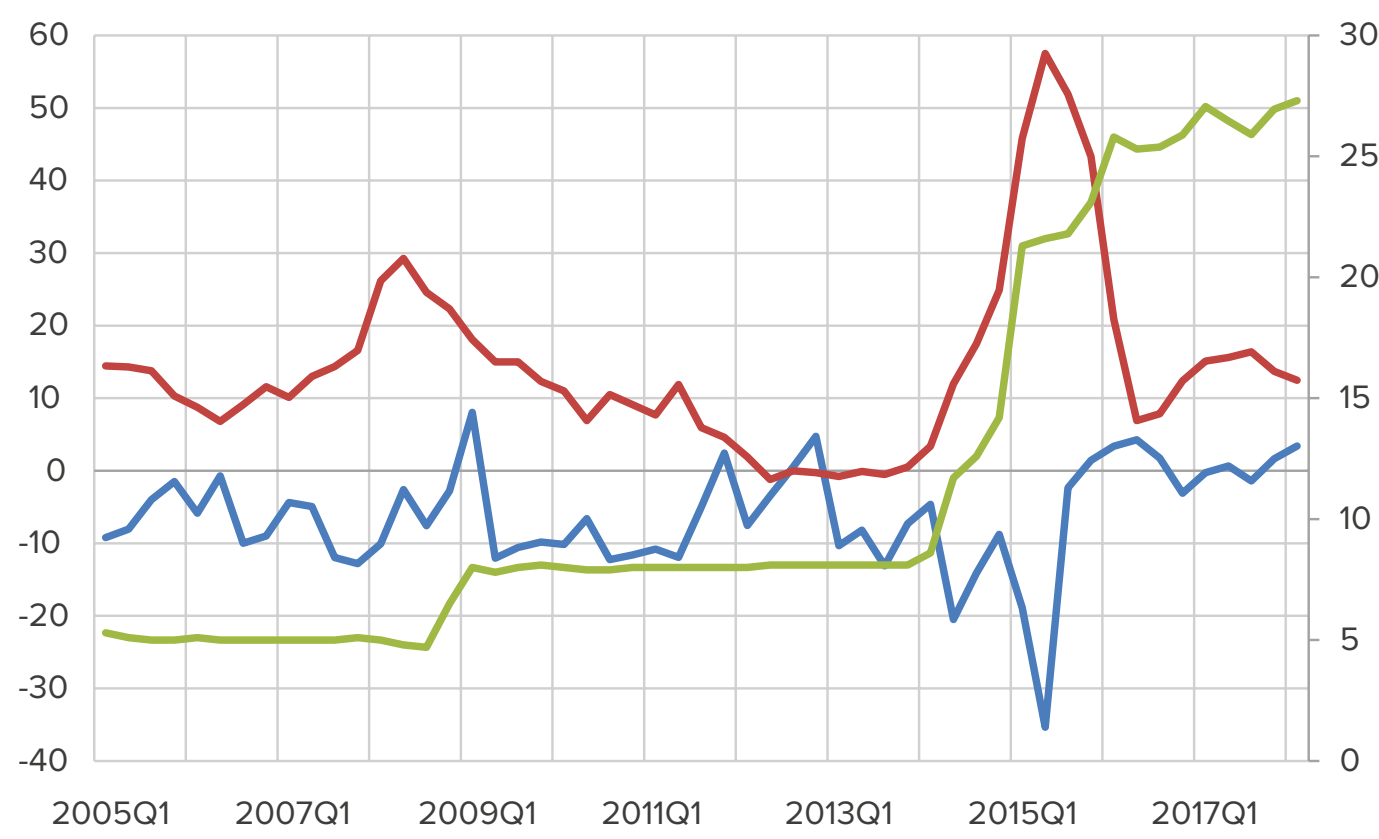

Real Interest Rate Gap — CPI, \% yoy $\quad$ UAH/USD (average), RHS 
Most of the time the real interbank rate has been markedly below its neutral level - under the exchange rate peg framework, during periods of strong capital inflow, monetary policy was accommodative, as the central bank relied on unsterilized $\mathrm{FX}$ interventions to maintain the peg. In 2008, these loose monetary conditions contributed to the severe BOP and currency crises. In 2014 and at the beginning of 2015, the depreciation pressure was not contained, as the interest rate had been rendered negative in real terms.

\subsection{Long-term values}

\section{Trend of the real exchange rate}

In our assessment of the long-run real exchange rate (LR RER) trend with the US, we rely heavily on Phillips et al. (2013), which introduces the External Balance Assessment methodology developed by the IMF's Research Department. We use coefficients from Table 5 of the paper to link LR RER appreciation with projections of changes in certain macroeconomic variables. See section IV of the paper for methodological clarifications.

Our results are summarized in Table 2 of this paper, and we estimate a $2 \%$ annual appreciation of LR RER against the US dollar. The approach requires the making of several assumptions, which are listed below:

- Ukrainian GDP is projected to grow by $4 \%$ annually in the long term. This estimate is close to current developments in peer economies, e.g. Poland, as well as Romania, Hungary, and the Czech Republic, which were recently able to increase their growth rates in the wake of the financial crisis. In fact, this growth rate is used by the NBU in its Quarterly Projection Model to represent potential GDP growth in a steady state. However, $4 \%$ is above the $3.2-3.5 \%$ projected for Emerging and Developing Europe in 2018-2022 in the IMF's World Economic Outlook (October 2017);

- Relative economic growth for Ukraine is $2 \%$, as long as it is calculated in comparison with the projected $2 \%$ GDP growth in the US. Projections for the US are taken as being equal to recent estimates of potential GDP growth made using the methodology of Laubach and Williams (2003);

The unfavorable demographic trend in Ukraine significantly restrains LR RER appreciation. The projected population growth in the US and the decline in Ukraine both contribute to the pace of negative $1 \%$ for the relative change in population. The negative demographic trend in turn causes population aging, which stimulates an increase in savings. Such trends increase the current account norm, which creates depreciation pressure on LR RER;

- The relative changes in population and relative projected GDP growth both shape relative GDP per capita, which is a proxy for productivity;

- Foreign exchange purchases (on average 1\% of GDP annually) are projected in line with attempts to achieve an adequate level of net international reserves, matching the IMF's composite measure. Thus, in the medium to long term the NBU will be forced to steadily increase the level of reserves in order to keep up them at a level in line with the growth of the economy and the financial sector. Given that capital flows are not fully free, they will be a restraining factor on RER appreciation;

- We estimate capital account openness to be 0.5 on a scale from 0 to 1 ;

- We do not expect other factors to have significant effects on RER in the long run. Specifically, there is no reason to assume any changes in risk aversion, the share of domestic debt owned by residents, commodity terms of trade, trade openness, or the real interest rate differential in the medium to long term;

- According to statistical data, the real sector in Ukraine seems to be overloaded with loans. This is the legacy of related-party lending schemes (or oligarch-style banking) that have dominated the Ukrainian banking system for decades. In fact, this was not banking per se, but rather a way for big businesses to finance itself. After large-scale reforms in the banking system, more than a half of bank loans were declared to be non-performing. We conservatively project no growth in the private credit to GDP ratio over the long term;

- We assume that price liberalization processes will be finished in the next few years. Thus, there will be no changes in the share of administered prices in the medium to long term.

The share of health expenditure in GDP in Ukraine is close to the level in peer countries. We assume that healthcare system reforms will lead to changes in the structure of such expenditures, but not in its share of GDP.

The sensitivity of this and some other assumptions is tested in section 4.3 of this paper. 
Table 2. Determinants of long-term real ER

\begin{tabular}{|c|c|c|c|}
\hline Variable & Coefficient & Changes in Ukraine & Impact \\
\hline Relative GDP per capita ${ }^{*} \mathrm{~K}$ controls & 0.52 & 3.0 & 1.6 \\
\hline Global risk aversion & -0.24 & 0 & 0 \\
\hline $\begin{array}{l}\text { Share of domestic debt owned by } \\
\text { residents }\end{array}$ & 0.34 & 0 & 0 \\
\hline Relative population growth & 3.50 & -1.0 & -3.5 \\
\hline Relative GDP in 5 years & 2.32 & 2.0 & 4.6 \\
\hline Terms of trade & 0.08 & 0 & 0 \\
\hline Avg (export, import)/GDP & -0.36 & 0 & 0 \\
\hline Share of admin. prices & -1.86 & 0 & 0 \\
\hline Health expenditures/GDP & 1.78 & 0 & 0 \\
\hline FX Net Reserves/GDP ${ }^{*} \mathrm{~K}$ controls & -0.72 & 1.0 & -0.7 \\
\hline Real rate differential ${ }^{*} \mathrm{~K}$ openness & 0.35 & 0 & 0 \\
\hline Private credit/GDP & 0.13 & 0 & 0 \\
\hline \multicolumn{3}{|c|}{ Long-term RER annual appreciation (Total) } & 2.0 \\
\hline
\end{tabular}

\section{Sovereign risk premium}

The steady state value of the sovereign risk premium in Ukraine is assumed to be at 3 percentage points. The premium exceeded this level in the first half of 2008 , and has never been lower than this since then. However, the recent enduring decline, on the background of the program with IMF and anticipated reforms, makes us optimistic about the long-term prospects. That level is above average since 2013 for Eastern European countries with investment ratings - at 2.2 percentage points ${ }^{2}$ (Figure 9).

Figure 9. Sovereign risk premium in peer economies, \%

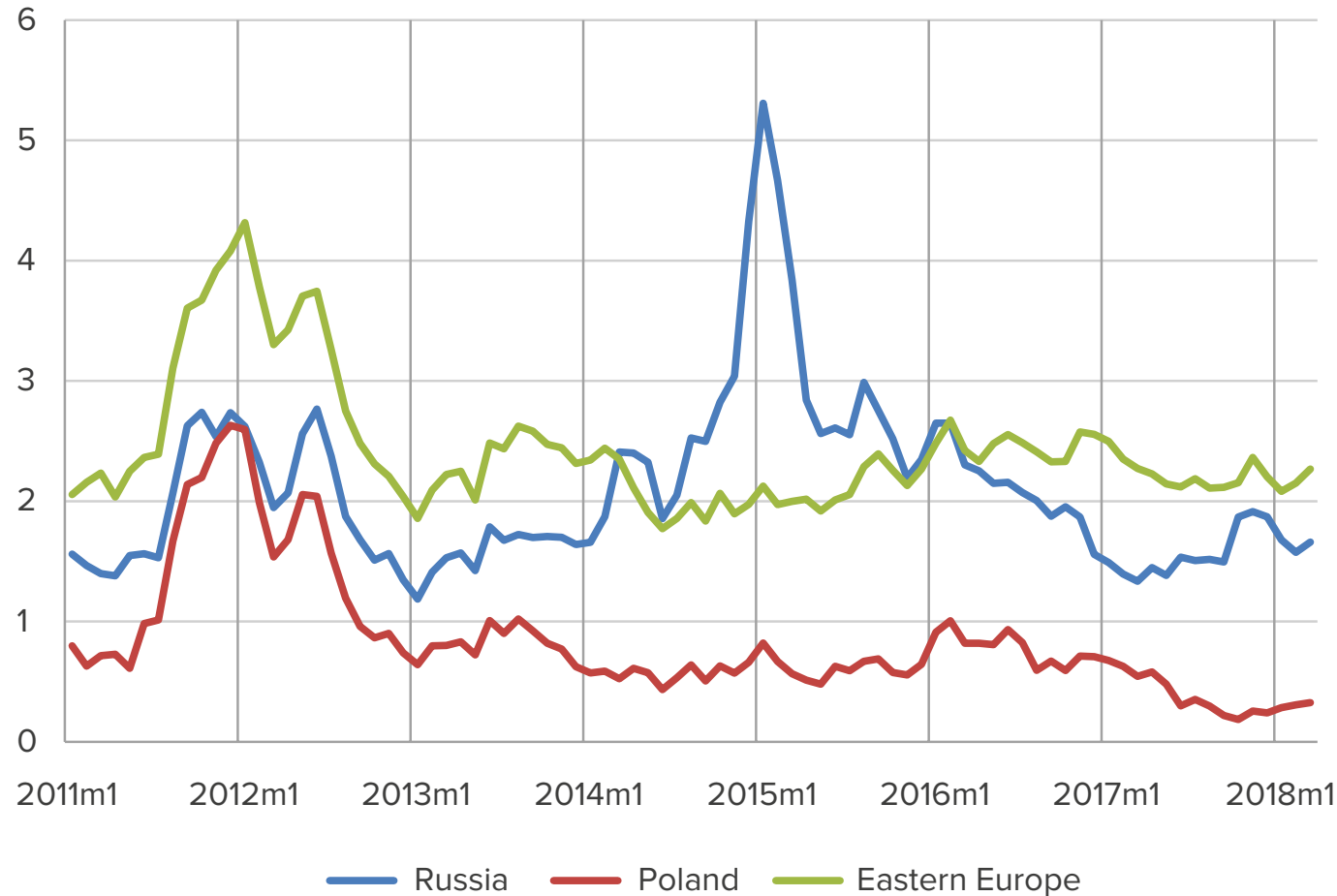

Source: Cbonds.com, own estimates.

${ }^{2}$ Cbonds.com 


\section{Real neutral interest rate in the US}

The long-term value of the real equilibrium interest rate in the US is projected to be equal to $1 \%$.

Holston et al. (2016), in their study of advanced economies (the Euro Area, Canada, the United States, and the United Kingdom) link real neutral interest rates to potential GDP growth. Both indicators have been slowing for at least the last 25 years, thus, future real rates cannot be calculated as a simple historical average. The reasons for this deceleration include demographic shifts and a slowdown in productivity growth. These reasons are common to all of the advanced economies. Furthermore, their real neutral interest rates dropped sharply after the crisis in 2008.

However, in the long run, the negative effects of the financial crisis are expected to subside, so real interest rates should come back to their pre-crisis values - around $1 \%$ for the United States according to the methodology of Laubach and Williams (2003). Moreover, Yellen (2016) states that $1 \%$ is the median long-term projection of the Federal Open Market Committee.

\section{Real neutral interest rate in Ukraine}

We assess the long-term value of the real neutral interest rate in Ukraine as a sum of the long-term values of the real natural interest rate in the United States and the Ukrainian sovereign risk premium, minus the long-term value of real ER appreciation. This gives a result of $2 \%$ annually. This number is expected to determine a neutral monetary policy over the long term.

\subsection{Long run sensitivity analysis}

Over the long term, the real neutral rate is a subject to uncertainty due to possible variations in its components.

First, investor sentiments may alter the sovereign risk premium. Our projections assume the convergence of Ukraine with its peer economies, which will lead to a relatively low risk premium of 3 percentage points. However, a swift convergence might result in an even lower rate of 2 percentage points, which is just below average for the country's Eastern European peers. On the other hand, a halting of reforms could bolster the risks and stall the premium rate at the current 4 percentage points. These options yield a possible diapason of the sovereign risk premium of 2-4 percentage points in the long run.

Second, the real natural interest rate in the United States will be determined on the global markets. According to estimates under the Laubach and Williams (2003) methodology as of the second half of 2017, the current rate is below zero, which is a historic low. A sluggish world economy may result in the rate get stuck halfway to $1 \%$ i.e. at $0.5 \%$. In contrast, faster world economy growth might yield a higher neutral interest rate of $1.5 \%$ - the pre-financial crisis value. Thus, the projected diapason is $0.5-1.5 \%$ in the long run.
One final source of uncertainty comes from assumptions about LR RER appreciation. The point projection for the long run is $2 \%$ yearly. However, historically over the last 10 years real exchange rate has mostly depreciated, which makes us conservative about projections for the future. The rate has had an appreciating trend as of the beginning of 2018, but we see zero as the lower bound for LR RER changes.

From the optimistic point of view, the current pace of appreciation may continue to increase to pre-financial crisis levels of around $3 \%$ annually. So the diapason of projections for LR RER appreciation spans 0-3\% annually.

According to Table 2, there are several macroeconomic variables that generate uncertainty in real ER projections:

- Capital account openness interacts with coefficients in the table, and thus influences the contributions of other variables. On a scale from 0 to 1 and all other things being equal, this factor may alter annual LR RER appreciation from $1.8 \%$ to $2.2 \%$. Higher capital openness yields lower appreciation. Jahan and Wang (2016) argue that 0.7 is the median value for emerging market economies. This value is associated with $1.9 \%$ annual appreciation;

- Ukrainian GDP is vulnerable to external conditions, while LR RER is sensitive to assumptions about its potential growth. A lowering of potential real GDP growth by 0.1 percentage points, all other things being equal, could lead to LR RER appreciation slowing by 0.3 percentage points. The last ten years of low GDP growth - even excluding the crisis periods - shifts the risk for LR RER to lower appreciation;

- LR RER appreciation is nearly as sensitive to relative population growth as to potential GDP growth. If relative population growth is as little as 0.1 percentage points higher, it could result in 0.3 percentage points higher LR RER appreciation.

In the case of an adverse macroeconomic scenario in Ukraine, its long term sovereign risk premium might hit its upper bound, and RER appreciation - its lowest. A favorable scenario would have the opposite effect. Given that the global neutral interest rate is independent of conditions in Ukraine, we will leave it at the central projection point of $1 \%$.

This combination of factors yields a diapason of $0-5 \%$ for the long-term projection of the neutral interest rate.

\subsection{Comparison with the international estimates}

This is the first study of the neutral interest rate in Ukraine, and so we are unable to compare our results with other works. However, it might be worth comparing our results for Ukraine with the results for other countries, as presented in Figure 10. 


\section{Figure 10. International estimates of neutral real interest rates, \%}

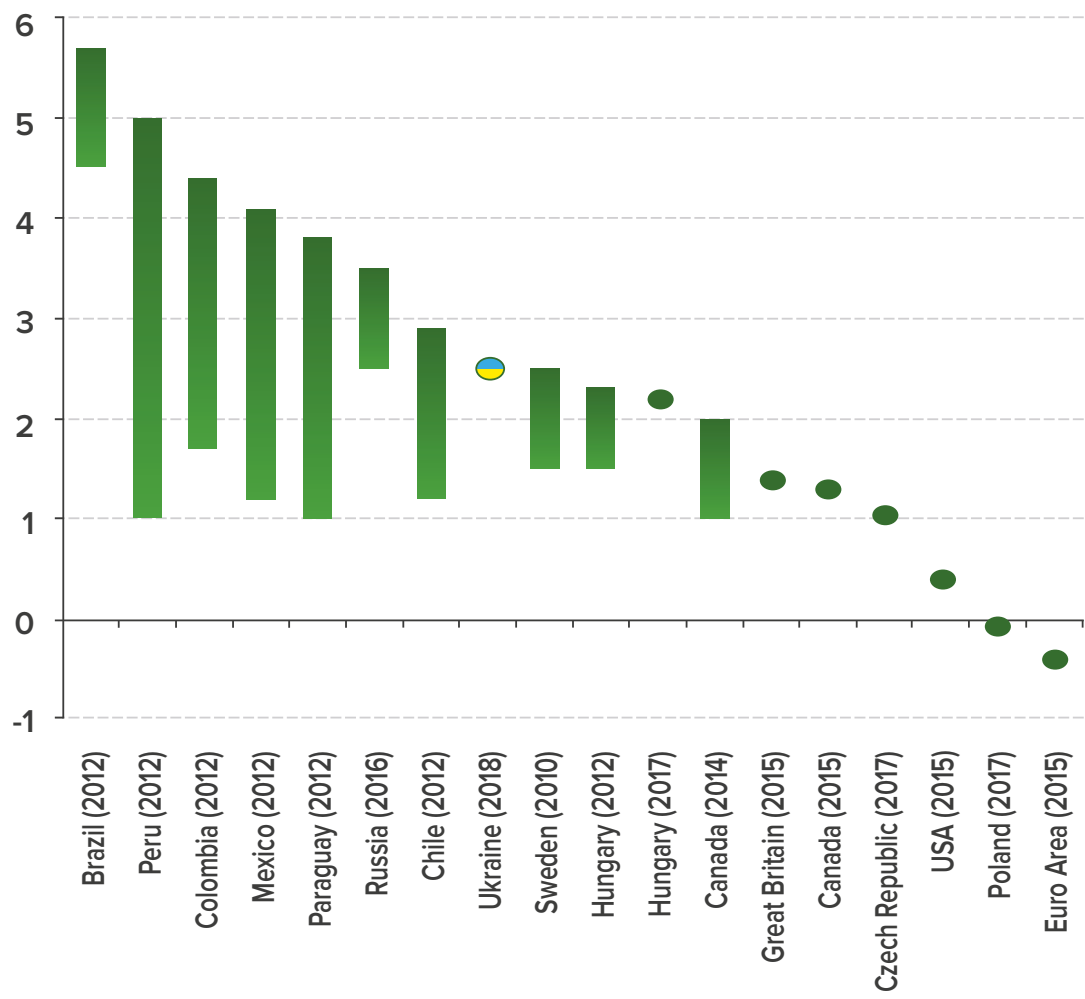

Source: Magud and Tsounta (2012) for Brazil, Peru, Colombia, Mexico, Paraguay, and Chile in 2012; Kreptsev et al. (2016) for Russia; Baksa et al. (2013) for Hungary in 2012; Stefanski (2017) for Czech Republic, Poland and Hungary in 2017; Sveriges Riksbank (2010) for Sweden; Mendes (2014) for Canada in 2014; Laubach and Williams (2017) for Canada, Great Britain, Euro Area, and USA in 2015.

That said, comparing the neutral rates of different countries could be misleading, as estimates can vary a lot depending on the methods used and the assumptions made. However, our estimate for Ukraine lies within the ranges seen in other studies of other countries.

The level of the neutral interest rate is close to the results obtained by Magud and Tsounta (2012) for most Latin American countries. Their average of estimates (the authors compare seven methods) is close to $2 \%$. Brazil has about $5 \%$, but it is rather a unique case, historically having the highest interest rates in the region.

Recent studies both of advanced and developing economies indicate rather low neutral interest rates, in the range of 0 to $2 \%$. This reflects ample global liquidity and other factors described in the Section 2.

\section{CONCLUSIONS}

In this paper, we estimated the neutral interest rate for Ukraine using a small open economy framework, based on uncovered interest rate parity. This approach is the most suitable, especially for policymaking purposes, in the case of the Ukrainian economy, which may rely on external sources of capital. We explored a semi-structural gap version of a dynamic New Keynesian small open economy model, and accounted for the trends in real exchange rate and risk premium. For empirical estimates of a time-varying neutral rate, we applied a Kalman filter algorithm to historical data.
Our findings show that the estimated neutral interest rate in Ukraine demonstrated significant variation over time, mainly reflecting swings in the risk premium, while the trend changes in the real exchange rate and the foreign neutral rate also contributed. In 2016 and 2017, the neutral rate in Ukraine declined to $2.5 \%$, driven both by a lowering sovereign risk premium and a return to a real exchange rate appreciation trend due to a recovery in productivity growth. Our projections suggest that over the long term, the neutral rate is to approach $2 \%$, reflecting a further decrease in the risk premium and an acceleration of real exchange rate appreciation trend. Meanwhile, the long term real neutral rate is a subject to uncertainty due to possible variations in its components, and is estimated to be in the range from 0 to $5 \%$, depending on the success of economic development in Ukraine.

Measuring the neutral rate provides a useful tool for policy analysis. For instance, it shows that in the past, shortterm interest rates remained below the neutral rate for prolonged periods during the exchange rate peg era (until 2014). This resulted in high and volatile inflation. Meanwhile, in the medium-term prospect, the NBU's key policy rate needs to be maintained at a level sufficiently higher than neutral level in order to ensure disinflation and stabilize expectations close to the inflation target. 


\section{REFERENCES}

- Anderson R.G., Buol J.J., Rasche R.H. (2004). A Neutral Federal Funds Rate? Monetary Trends, (Dec).

- Archibald J., Hunter L. (2001). What is the Neutral Real Interest Rate, and How Can We Use It? Reserve Bank of New Zealand Bulletin, Vol. 64, No. 3, pp. 15-28.

- Baksa D., Felcser D., Horváth Á., Norbert Kiss M., Csaba K., Balázs K., Gábor Dániel S., Katalin S. (2013). Neutral Interest Rate in Hungary. MNB Bulletin, Vol. 8, Special Issue, pp. 7-13.

- Ball L., Gagnon J., Honohan P., Krogstrup S. (2016). What Else Can Central Banks Do? ICMB International Center for Monetary and Banking Studies, Geneva.

- Barsky R., Justiniano A., Melosi L. (2014). The Natural Rate of Interest and Its Usefulness for Monetary Policy. American Economic Review, Vol. 104, No. 5, pp. 37-43.

- Basdevant O., Björksten N., Karagedikli Ö. (2004). Estimating a Time Varying Neutral Real Interest Rate for New Zealand, Discussion Paper Series, No. 2004/01, Reserve Bank of New Zealand.

- Carvalho C., Ferrero A., Nechio F. (2016). Demographics and Real Interest Rates: Inspecting the Mechanism. European Economic Review, Vol. 88, Issue C, pp. 208-226.

- Coats W., Laxton D., Rose D. (2003). The Czech National Banks Forecasting and Policy Analysis System. Czech National Bank, Prague.

- Coletti D., Hunt B., Rose D., Tetlow R. (1996). The Bank of Canada's New Quarterly Projection Model. Part 3, The Dynamic Model: QPM, Bank of Canada.

- Cúrdia V., Ferrero A., Ng G.C., Tambalotti A. (2015). Has US Monetary Policy Tracked the Efficient Interest Rate? Journal of Monetary Economics, Vol. 70, Issue C, pp. 72-83.

- De Gregorio J., Edwards S., Valdes R. O. (2000). Controls on Capital Inflows: do they Work? Journal of Development Economics, Vol. 63, No. 1, pp. 59-83.

- Del Negro M., Giannoni M.P., Schorfheide F. (2015). Inflation in the Great Recession and New Keynesian Models. American Economic Journal: Macroeconomics, Vol. 7, No. 1, pp. 168-196.

- Forbes K.J., Warnock F.E. (2012). Capital Flow Waves: Surges, Stops, Flight, and Retrenchment. Journal of International Economics, Vol. 88, No. 2, pp. 235-251.

- Giammarioli N., Valla N. (2004). The Natural Real Interest Rate and Monetary Policy: A Review. Journal of Policy Modeling, Vol. 26, No. 5, pp. 641-660.

- Grui A., Lepushynskyi V. (2016). Applying FX Interventions as an Additional Instrument Under Inflation Targeting: The Case of Ukraine. Visnyk of the National Bank of Ukraine, No. 238, pp. 39-56.

- Gunnarsdóttir T., Rehnholm A. (2011). Effectiveness of Capital Controls in a Financial Crisis: The Case of Iceland. Stockholm School of Economics, M.Sc. Thesis in Economics.
- Hamilton J.D., Harris E.S., Hatzius J., West K.D. (2016). The Equilibrium Real Funds Rate: Past, Present, and Future. IMF Economic Review, Vol. 64, No. 4, pp. 660-707.

- He D., Wang H., Yu X. (2014). Interest Rate Determination in China: Past, Present, and Future. HKIMR, No. 04/2014.

- Holston K., Laubach T., Williams J. C. (2017). Measuring the Natural Rate of Interest: International Trends and Determinants. Journal of International Economics, Vol. 108, Issue S1, pp. S59- S75.

- International Monetary Fund (2014). World Economic Outlook, April 2014, Perspective on Global Real Interest Rates.

- International Monetary Fund (2017). World Economic Outlook, October 2017, Short-Term Recovery, Long-Term Challenges.

- Jahan S., Wang D. (2016). Capital Account Openness in Low-income Developing Countries: Evidence from a New Database. IMF Working Paper, No. 16/252.

- Keynes J.M. (1936). The General Theory of Employment, Interest and Money. Reprinted in The Collected Writings of John Maynard Keynes, 7.

- Kreptsev D., Porshakov A., Seleznev S., Siniakov A. (2016). Equilibrium Interest Rate: Estimations for Russia. Bank of Russia Working Paper Series, No. 13/2016.

- Laubach T., Williams J.C. (2003). Measuring the Natural Rate of Interest. Review of Economics and Statistics, Vol. 85, No. 4, pp. 1063-1070.

Lucas R.E. (1976). Econometric Policy Evaluation: A Critique. Carnegie-Rochester conference series on public policy, Vol. 1, No. 1, pp. 19-46, North-Holland.

- Magud N., Tsounta E. (2012). To Cut or Not to Cut? That is the (Central Bank's) Question. In Search of the Neutral Interest Rate in Latin America. IMF Working Paper, No. 12/243.

- Mendes R.R. (2014). The Neutral Rate of Interest in Canada. Bank of Canada Discussion Paper, No. 2014-5.

- Miniane J., Rogers, J. H. (2007). Capital Controls and the International Transmission of US Money Shocks. Journal of Money, Credit and Banking, Vol. 39, No. 5, pp. 1003-1035.

- Mundell R.A. (1963). Capital Mobility and Stabilization Policy Under Fixed and Flexible Exchange Rates. Canadian Journal of Economics and Political Science, Vol. 29, No. 4, pp. 475-485.

- Nikolaychuk S., Sholomytskyi Y. (2015). Using Macroeconomic Models for Monetary Policy in Ukraine. Visnyk of the National Bank of Ukraine, No. 233, pp. 54-64.

- Parker J.A. (2007). Euler Equations. Unpublished, Princeton University.

- Pasricha G., Falagiarda M., Bijsterbosch M., Aizenman J. (2015). Domestic and Multilateral Effects of Capital Controls in Emerging Markets. NBER Working Paper, No. 20822. 
- Perrelli R., Roache S.K. (2014). Time-Varying Neutral Interest Rate - The Case of Brazil. IMF Working Paper, No. $14 / 84$.

- Pescatori A., Turunen J. (2015). Lower for Longer: Neutral Rates in the United States. IMF Working Papers, No. 15/135.

- Phillips S., Catão L., Ricci L., Bems R., Das M., Di Giovanni J., Unsal D.F., Castillo M., Lee J., Rodriguez M. Vargas M. (2013). The External Balance Assessment (EBA) Methodology. IMF Working Papers, No. 13/272.

- Saborowski C., Sanya S., Weisfeld H., Yepez J. (2014). Effectiveness of Capital Outflow Restrictions. IMF Working Paper, No. 14/8.

- Stefanski M. (2017). Natural Rate of Interest: Spillovers From Advanced Economies to Central and Eastern Europe. Presentation at NBP-SNB Joint Seminar, 11 May, Zurich.

- Svensson L. (1997). Inflation Forecast Targeting: Implementing and Monitoring Inflation Targets. European Economic Review, Vol. 41, No. 6, pp. 1111-1146.
- Sveriges Riksbank (2010). What is a Normal Level for the Repo Rate? Monetary Policy Report, February 2010, pp. 43-46.

- Taylor J.B. (1993). Discretion Versus Policy Rules in Practice. Carnegie-Rochester Conference Series on Public Policy, Vol. 39, pp. 195-214.

- Wicksell K. (1936). Interest and Prices. 1898. Translated by RF Kahn, with an introduction by Bertil Ohlin.

- Woodford M. (2003). Interest and Prices. Princeton University Press.

- Yellen J. (2016). The Federal Reserve's Monetary Policy Toolkit: Past, Present, and Future. Washington: Board of Governors of the Federal Reserve System. 